\title{
Detection of viral hemorrhagic septicemia in round gobies in New York State (USA) waters of Lake Ontario and the St. Lawrence River
}

\author{
G. H. Groocock ${ }^{1}$, R. G. Getchell ${ }^{1}$, G. A. Wooster $^{1}$, K. L. Britt ${ }^{1}$, W. N. Batts ${ }^{2}$, \\ J. R. Winton ${ }^{2}$, R. N. Casey ${ }^{1}$, J. W. Casey ${ }^{1}$, P. R. Bowser ${ }^{1, *}$ \\ ${ }^{1}$ Aquatic Animal Health Program, Department of Microbiology and Immunology, College of Veterinary Medicine, \\ Cornell University, Ithaca, New York 14853, USA \\ ${ }^{2}$ US Geological Survey, Western Fisheries Research Center, 6505 NE 65th Street, Seattle, Washington 98115-5016, USA
}

\begin{abstract}
In May 2006 a large mortality of several thousand round gobies Neogobius melanostomus (Pallas, 1814) occurred in New York waters of the St. Lawrence River and Lake Ontario. Necropsies of sampled fish from these areas showed pallor of the liver and gills, and hemorrhagic areas in many organs. Histopathologic examination of affected tissues revealed areas of necrosis and hemorrhage. Inoculations of fathead minnow Pimephales promelas (Rafinesque, 1820) cell cultures with dilutions of tissue samples from the necropsied gobies produced a cytopathic effect within $5 \mathrm{~d}$ postinoculation. Samples of cell culture supernatant were tested using RT-PCR and confirmed the presence of viral hemorrhagic septicemia virus (VHSV). Sequence analysis of the VHSV isolate resulted in its assignment to the type-IVb subgroup. The detection of VHSV in a relatively recent invasive fish species in the Great Lakes and the potential impact of VHSV on the ecology and economy of the area will require further investigation and careful management considerations.
\end{abstract}

KEY WORDS: Viral hemorrhagic septicemia $\cdot$ VHSV $\cdot$ Round goby $\cdot$ New York State

\section{INTRODUCTION}

Lake Ontario and the St. Lawrence River are economically and ecologically important water systems supporting a large variety of fish species. Round gobies Neogobius melanostomus (Pallas, 1814) are a recently invasive species to the Great Lakes, first detected in the early 1990s (Jude et al. 1992). Since that time, their population has expanded rapidly and they have become an important part of the food chain in these ecosystems.

In early May 2006 the New York State Department of Environmental Conservation (NYSDEC) received reports of large scale fish kills involving several thousand round gobies on the St. Lawrence River near Cape Vincent, New York. Over the course of subsequent weeks, the NYSDEC received additional reports of locations in US waters on the St. Lawrence River and Lake Ontario where hundreds of dead and dying round gobies were observed. Collections of round gobies from the initial fish kill event and from a subsequent fish kill that occurred in the mouth of Sandy Creek, Lake Ontario, were submitted by the NYSDEC to the Aquatic Animal Health Program (AAHP) at the College of Veterinary Medicine, Cornell University, for diagnostic evaluation.

\section{MATERIALS AND METHODS}

Samples of round gobies were received by the AAHP at Cornell University from 2 locations. The first sample consisted of 23 moribund and dead fish from the St. Lawrence River near Cape Vincent, New York. On 4 May 2006, divers from the NYSDEC collected dead and moribund gobies from this area and shipped them by courier immediately to the AAHP at the Col- 
lege of Veterinary Medicine, Cornell University. The fish arrived at Cornell in moribund or freshly dead condition and were processed for diagnostic evaluation. The second sample consisted of 9 dead round gobies collected on 15 May 2006 from Sandy Creek, Lake Ontario, west of Rochester, New York. These fish were transported on ice to the AAHP at Cornell University.

Cape Vincent, St. Lawrence River samples. All moribund fish were euthanized with an overdose of MS222 (tricaine methanesulfonate, Western Chemical) in water. Eight fish were processed for diagnostic evaluation. The remaining 15 fish were frozen whole at $-20^{\circ} \mathrm{C}$ for future evaluation if necessary. The procedure for diagnostic evaluation is described by Noga (1996) and included collecting skin scrapings and gill clip samples, sterile collection of posterior kidney samples for bacteriology, gross pathology and collection of tissues for histopathology and virology. Samples of liver, kidney, spleen and gonad were collected in 2 pooled samples for detection of viral agents. The first pooled sample (Sample A) included tissues from gobies that were dead at the time of presentation. The second pooled sample (Sample B) included fish that were moribund at the time of presentation. These samples collected for virus isolation were processed as described in the following sections. Attempts at bacterial isolation consisted of cultures taken from the posterior kidneys that were streaked onto blood agar (TSA II $5 \%$ $\mathrm{SB}, \mathrm{BBL}^{\mathrm{TM}}$, Becton Dickinson). These cultures were incubated for $7 \mathrm{~d}$ at $21^{\circ} \mathrm{C}$. Samples of intestines, gut contents and liver were collected to test additionally for type-E botulism by PCR (Getchell et al. 2006).

Irondequoit Bay, Lake Ontario samples. Five fish were processed for diagnostic evaluation. Skin scrapings, gill clips and histopathology were not performed on these fish as the samples were moderately autolysed and the diagnostic significance of these tissues was considered marginal for these samples. Due to the condition of the specimens further processing of these fish was limited to attempts at virus isolation. No attempts at bacterial isolation were performed. Samples of liver, kidney, spleen, swim bladder and gonad were collected from each of the 5 fish for this purpose and processed as described in the following sections.

Gross pathology and histopathology. Fish were examined for the presence of external and internal lesions. Tissues for histopathology were fixed in $10 \%$ neutral buffered formalin. Bony tissues, such as gill arches, were additionally decalcified for 5 to $7 \mathrm{~d}$ in $14 \%$ disodium EDTA (Sigma). All tissues were sectioned at $5 \mu \mathrm{m}$ and stained with hematoxylin and eosin (H\&E) for microscopic evaluation (Luna 1968). Immunohistochemical stains were performed on select tissue sections using the standard procedures for the streptavidin-biotin immunoperoxidase technique.
Virus isolation. The protocols used followed the standard guidelines published by the American Fisheries Society (2004) and the Office International des Epizooties (OIE) (2003). Tissue samples were prepared at 1:10 dilutions by aseptically weighing $0.5 \mathrm{~g}$ of tissue and adding $4.5 \mathrm{ml}$ Minimal Essential Medium with Hanks' salts (Gibco ${ }^{\oplus}$, Invitrogen) prepared with $5 \%$ fetal bovine serum $\left(\right.$ Gibco $^{\circledR}$, Invitrogen), penicillin (200 $\left.\mathrm{IU} \mathrm{ml}^{-1}\right)$, streptomycin $\left(200 \mu \mathrm{g} \mathrm{ml}^{-1}\right)$, glutamine $\left(0.584 \mathrm{mg} \mathrm{m}^{-1}\right)\left(\right.$ Gibco $^{\circledR}$, Invitrogen) and HEPES buffer $\left(1 \mathrm{M} 0.015 \mathrm{ml} \mathrm{ml}^{-1}\right)\left(\right.$ Gibco $^{\circledR}$, Invitrogen), hereafter referred to as HMEM- $5 \% 2 \times$ PSG + HEPES. The tissue and media were homogenized using a Stomacher ${ }^{\circledR} 80$ homogenizer (Seward) for $2 \mathrm{~min}$. The homogenized media were kept on ice for $10 \mathrm{~min}$, then centrifuged (Multifuge $^{\mathrm{TM}}$, American Scientific Products) at $500 \times g$ for $5 \mathrm{~min}$. Inocula were prepared by pipetting off the homogenized media, avoiding the pellet, and sterile filtering through $0.2 \mu \mathrm{m}$ biological filters $\left(\right.$ Acrodisc $^{\circledR}$, Pall Life Sciences). One milliliter of the inocula was placed on fresh monolayers of fathead minnow Pimephales promelas (Rafinesque, 1820) (FHM) cell cultures (American Type Culture Collection CCL 42; Gravell \& Malsberger 1965) in $50 \mathrm{ml}$ cell culture flasks (Corning). Flasks containing inoculations were placed on a slow-speed orbital rocker (model PS-M3D, Grant Instruments) at $8 \mathrm{rpm}$ at $21^{\circ} \mathrm{C}$ for $45 \mathrm{~min}$. Finally, an additional $4 \mathrm{ml}$ of the medium, HMEM-5\% $2 \times$ PSG + HEPES, was added to each flask. The inoculated cells were incubated at $15^{\circ} \mathrm{C}$ and examined for the presence of cytopathic effects (CPE) daily for $21 \mathrm{~d}$ post-inoculation. Initial identity of the virus was confirmed using RT-PCR using viral hemorrhagic septicemia virus (VHSV)-specific primers followed by sequencing of the glycoprotein (G) gene as described by Elsayed et al. (2006).

Samples of supernatant from cell cultures exhibiting CPE were sent to the OIE Reference Laboratory for VHSV at the Danish Institute for Food and Veterinary Research, Community Reference Laboratory for Fish Diseases, Denmark, for VHSV PCR evaluation.

\section{RESULTS}

\section{Gross pathology}

On gross necropsy all the fish examined showed a wide range of signs indicative of a hemorrhagic disease (Table 1). Most notable were signs of anemia indicated by pale coloration to the gill lamellae and pale livers seen in many of the fish examined. Hemorrhagic areas were seen in many organs, in particular the omentum, abdominal fat, gonads, liver, muscle tissue (Fig. 1), skin and fins. None of the fish examined had food in their 
Table 1. Neogobius melanostomus. Summary of gross pathology observed in round gobies involved in mortality events and submitted for disease diagnostic evaluation. $\mathrm{F}=$ female, $\mathrm{M}=$ male; $\mathrm{Y}=$ presence in sample of pathology described

\begin{tabular}{|c|c|c|c|c|c|c|c|c|c|c|c|c|c|c|}
\hline \multirow[b]{2}{*}{$\begin{array}{l}\text { Fish } \\
\text { no. }\end{array}$} & \multirow[b]{2}{*}{ Sex } & \multirow[b]{2}{*}{$\begin{array}{l}\text { Length } \\
\text { (mm) }\end{array}$} & \multirow[b]{2}{*}{$\begin{array}{l}\text { Weight } \\
\text { (g) }\end{array}$} & \multirow[b]{2}{*}{$\begin{array}{c}\text { Body } \\
\text { condition }\end{array}$} & \multirow[b]{2}{*}{ 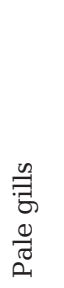 } & \multirow[b]{2}{*}{ 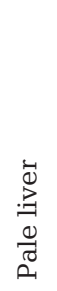 } & \multicolumn{6}{|c|}{ Pathology } & \multirow[b]{2}{*}{ 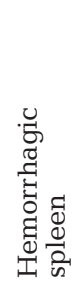 } & \multirow[b]{2}{*}{ 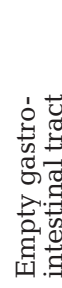 } \\
\hline & & & & & & & 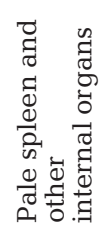 & 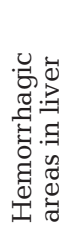 & 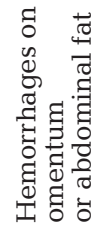 & 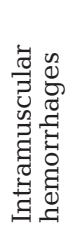 & 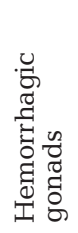 & 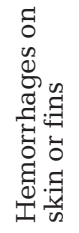 & & \\
\hline \multicolumn{15}{|c|}{ Cape Vincent fish } \\
\hline 1 & $\mathrm{~F}$ & 166 & 73.5 & Good & & $\mathrm{Y}$ & & & & & $\mathrm{Y}$ & & & $\mathrm{Y}$ \\
\hline 2 & $\mathrm{~F}$ & 182 & 101.6 & Good & $\mathrm{Y}$ & $\mathrm{Y}$ & & & $\mathrm{Y}$ & & $\mathrm{Y}$ & & & $\mathrm{Y}$ \\
\hline 3 & $\mathrm{~F}$ & 167 & 72.1 & Good & $\mathrm{Y}$ & $\mathrm{Y}$ & & & $\mathrm{Y}$ & & & & & $\mathrm{Y}$ \\
\hline 4 & $\mathrm{~F}$ & 98 & 19.8 & Good & $\mathrm{Y}$ & $\mathrm{Y}$ & & & $\mathrm{Y}$ & $\mathrm{Y}$ & & $\mathrm{Y}$ & & $\mathrm{Y}$ \\
\hline 5 & $\mathrm{~F}$ & 100 & 15.6 & Good & & $\mathrm{Y}$ & & & & & & $\mathrm{Y}$ & & $\mathrm{Y}$ \\
\hline 6 & $\mathrm{M}$ & 163 & 65.0 & Thin & & $\mathrm{Y}$ & & & & & & $\mathrm{Y}$ & & $\mathrm{Y}$ \\
\hline 7 & $\mathrm{M}$ & 131 & 36.5 & Thin & $\mathrm{Y}$ & $\mathrm{Y}$ & & & $\mathrm{Y}$ & $\mathrm{Y}$ & & $\mathrm{Y}$ & & $\mathrm{Y}$ \\
\hline 8 & M & 108 & 21.5 & Good & & & & Y & & & & & & $\mathrm{Y}$ \\
\hline \multicolumn{15}{|c|}{ Sandy Creek fish } \\
\hline 1 & $\mathrm{M}$ & 189 & 109 & Good & & & & $\mathrm{Y}$ & & $\mathrm{Y}$ & $\mathrm{Y}$ & & $\mathrm{Y}$ & $\mathrm{Y}$ \\
\hline 2 & $\mathrm{M}$ & 180 & 85 & Good & & $\mathrm{Y}$ & & & & & $\mathrm{Y}$ & & & $\mathrm{Y}$ \\
\hline 3 & M & 150 & 54 & Good & & & & $\mathrm{Y}$ & & & & $\mathrm{Y}$ & & $\mathrm{Y}$ \\
\hline 4 & $\mathrm{M}$ & 158 & 61 & Good & & $\mathrm{Y}$ & & & & & & & & $\mathrm{Y}$ \\
\hline 5 & $\mathrm{M}$ & 149 & 57 & Good & & $\mathrm{Y}$ & $\mathrm{Y}$ & & & & & $\mathrm{Y}$ & & $\mathrm{Y}$ \\
\hline
\end{tabular}

gastrointestinal tracts. No parasites were observed on examination of skin scrapes and gill clips from the Cape Vincent fish.

\section{Histopathology}

The affected hepatocytes appeared severely vacuolated with occasional pyknotic and karyolytic nuclei. The posterior renal tissue was similarly affected with evidence of scattered individual cell necrosis. There was moderate melanin deposition on the renal periphery, which may be associated with a prolonged period of stress. There was severe splenic parenchymal necrosis and depletion characterized by abundant numbers of individual cell necrosis (Fig. 2). In intramuscular hemorrhagic areas, extravasated erythrocytes were seen between intact muscle fibers. The gonadal and gill tissue examined appeared normal. Immunohistochemistry staining for vonWillebrand's factor and CD31 to differentiate endothelial cells was inconclusive.

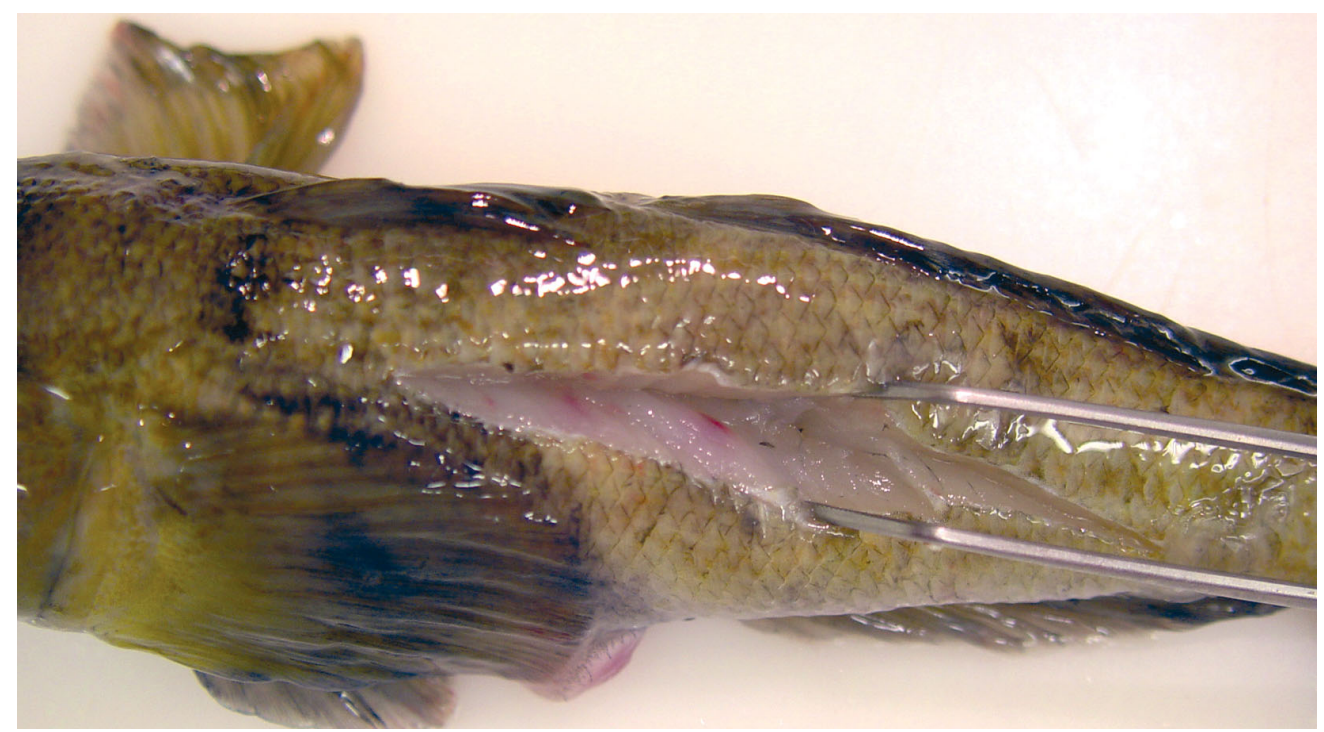

Fig. 1. Neogobius melanostomus. Gross pathology image of a round goby with intramuscular petechial hemorrhages 


\section{Bacteriology}

Cultures for bacterial pathogens collected from the posterior kidneys and streaked onto blood agar (TSA II $5 \% \mathrm{SB}, \mathrm{BBL}^{\mathrm{TM}}$, Becton Dickinson) media produced no significant bacterial growth after $7 \mathrm{~d}$ incubation at $21^{\circ} \mathrm{C}$. PCR testing of the Cape Vincent fish for botulinum type-E toxin gene produced a negative result.

\section{Virology}

CPE were detected in all FHM cultures 5 d postinoculation. Visible effects varied from destruction of the monolayer (Fig. 3) to areas of rounded refractile cells. Subsequent passages of cells showed attenuation of the CPE. In some cases second passage inoculations, which destroyed the monolayer, only produced areas of focal CPE in the third passage.

Samples of supernatant from first passage flasks with CPE were collected, subjected to RT-PCR testing for VHSV and subsequently sequenced as described by Elsayed et al. (2006). A positive RT-PCR result was obtained in all cases. The nucleotide sequence of the central region of the G-gene of the round goby isolate differed by only a single nucleotide from the VHSV isolate recovered from muskellunge Esox masquinongy (Mitchill, 1824) in Lake St. Clair in 2003 (Elsayed et al. 2006). Culture fluids from flasks inoculated with Samples A and B from Cape Vincent were submitted to the OIE reference laboratory in Denmark. A positive result was obtained by PCR testing for these samples, confirming the presence of VHSV in these fish.

\section{DISCUSSION AND CONCLUSIONS}

The gross pathological changes seen in these round gobies were consistent with the internal signs of VHSV infection described for salmonids (Wolf 1988). PCR testing for VHSV by 2 independent laboratories confirmed the identification of this virus.

Viral hemorrhagic septicemia virus is a Rhabdovirus well known for causing mortalities in both rainbow trout Oncorhynchus mykiss (Walbaum, 1792) (Castric \& de Kinkelin 1980) and turbot Scophthalmus maximus (Linnaeus, 1758) (Schlotfeldt et al. 1991) in Europe. The disease caused by VHSV is classified as reportable to the World Organization for Animal Health (OIE). VHSV has been detected in the USA as early as 1988 in anadromous salmonids in the Pacific Northwest (Winton et al. 1991, Meyers et al. 1992, 1994). In 2003 VHSV was detected in freshwater in muskellunge in Lake St. Clair, Michigan (Elsayed et al. 2006) and in freshwater drum Aplodinotus grunniens (Rafinesque,
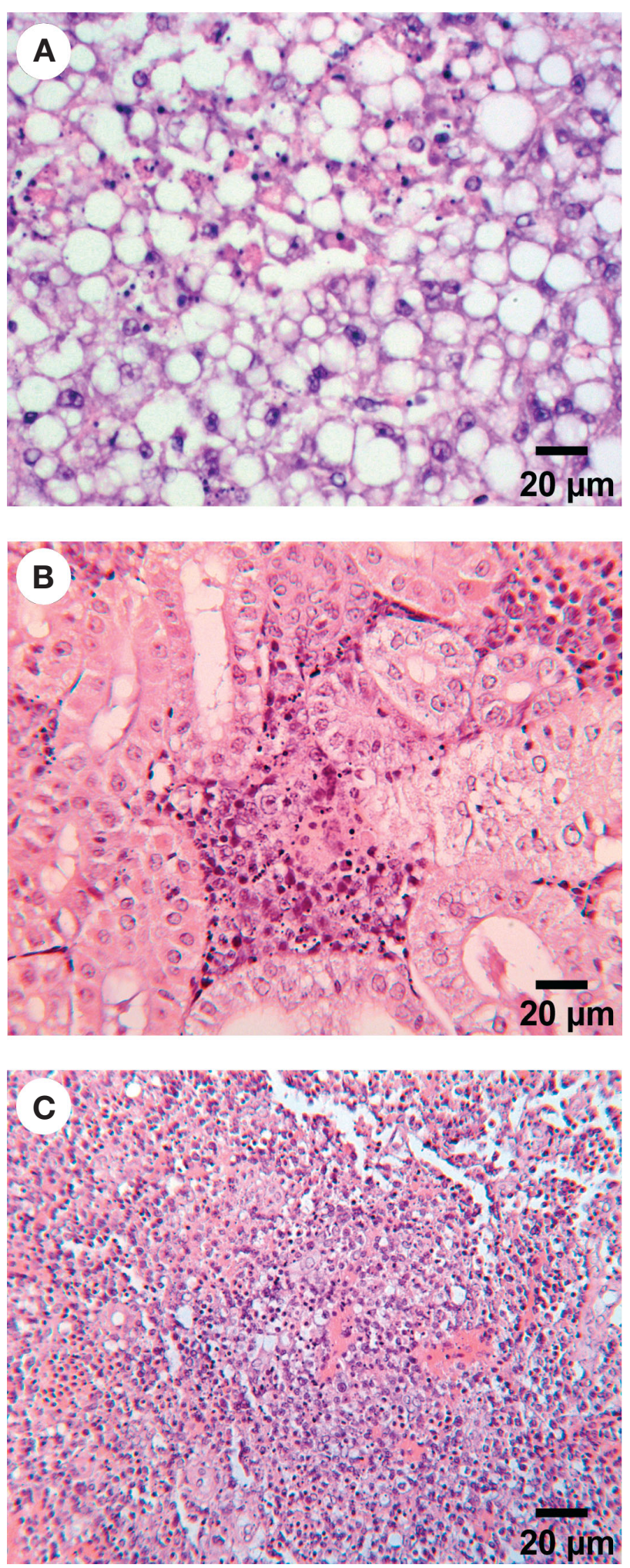

Fig. 2. Neogobius melanostomus. Microscopic images (H\&E stain, 40×) of histological tissue sections. (A) Vacuolated hepatocytes with occcasional pyknotic and karyolitic nuclei. (B) Renal individual cell necrosis and melanin deposition.

(C) Severe splenic parenchymal necrosis and depletion 


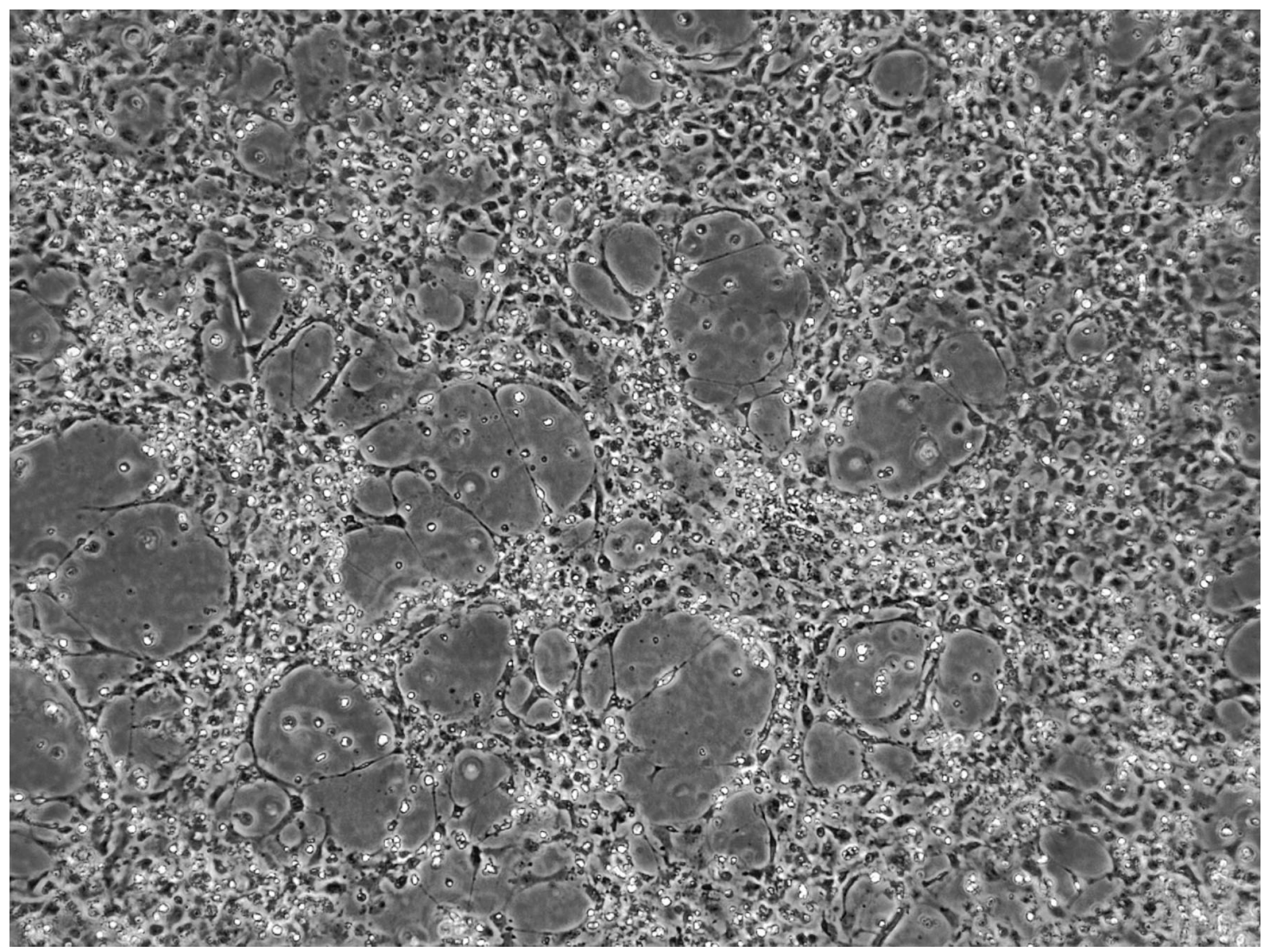

Fig. 3. Pimephales promelas. Cytopathic effect observed in fathead minnow (FHM) cell monolayers at $4 \mathrm{~d}$ post-inoculation

1819) in 2005 from the Bay of Quinte, Lake Ontario, Canada (Canada Cooperative Wildlife Health Centre 2005).

The isolate found in these round gobies (GenBank accession number EF564588) was essentially genetically identical to the VHSV type-IVb isolate described in muskellunge from Lake St. Clair (Elsayed et al. 2006). The North American VHSV type-IV isolate is known to infect a wide range of fish species in the Pacific Northwest (Hedrick et al. 2003). It is apparent from the wide genetic diversity between round gobies and muskellunge that the type-IVb isolate has a similarly broad host species range amongst freshwater fish. The 2006 mortalities in round gobies are probably part of a basin-wide VHSV type IVb (Elsayed et al. 2006) epizootic affecting multiple fish species.

The detection of VHSV in round gobies is an important finding in that it identifies another species of susceptible hosts in the Great Lakes. It also confirms the presence of VHSV in fish in the US waters of the Lake Ontario and St. Lawrence River. The mortality event that occurred in association with this virus is very disconcerting as it demonstrates the potential effect that VHSV can have on the ecology of these water systems. With large numbers of round gobies moribund or dead, the potential to transmit the virus to other species is greatly increased. As of June 2006 reports of suspect VHSV affecting other species of fish in the Lake Ontario and St. Lawrence River area included muskellunge, burbot Lota lota (Linnaeus, 1758) and smallmouth bass Micropterus dolomieu (Lacepède, 1802); however, as of this time, no reports of affected salmonids have been received. Particularly important is the infection of muskellunge with VHSV, which may have a serious economic impact on the area as the St. Lawrence River is renowned for its muskellunge sport fishery.

It is not known how viral VHSV entered the St. Lawrence River, but it is probably a combination of factors that played a role, including natural fish movement and movement of fish due to human influence. The close gene sequence similarity between this round goby isolate and the previously described muskellunge isolate (Elsayed et al. 2006) may indicate that this is a newly emerging viral strain affecting a naïve population. Finally, the presence and establishment of an OIE reportable disease in a major connecting waterway will require careful management to prevent further spread of this disease to naïve areas. 
Acknowledgements. We thank the fisheries biology staff of the New York State Department of Environmental Conservation for supplying fresh specimens for diagnostic evaluation. Particular thanks to Mr. Stephen Frattini, AAHP for technical assistance and Dr. Ana Alcaraz, Section of Anatomic Pathology, Department of Biomedical Sciences, College of Veterinary Medicine, Cornell University, for assistance with histopathology interpretation. K.L.B. was the recipient of a Summer AQUAVET Research Fellowship, through the AQUAVET Program administered by the School of Veterinary Medicine, University of Pennsylvania, and the College of Veterinary Medicine at Cornell University.

\section{LITERATURE CITED}

American Fisheries Society (2004) Suggested procedures for the detection and identification of certain finfish and shellfish pathogens. American Fisheries Society, Bethesda, MD

Canada Cooperative Wildlife Health Center (2005) A mortality event in freshwater drum (Aplodinotus grunniens) from Lake Ontario, associated with viral hemorrhagic septicemia (VHSV), type IV. Wildl Health Centre Newsl 11(1):10

Castric J, de Kinkelin P (1980) Occurrence of viral haemorrhagic septicaemia in rainbow trout Salmo gairdneri Richardson reared in sea water. J Fish Dis 3:21-27

Elsayed E, Faisal M, Thomas M, Whelan G, Batts W, Winton J (2006) Isolation of viral hemorrhagic septicemia virus from muskellunge, Esox masquinongy (Mitchill), in Lake St. Clair, Michigan, USA reveals a new sublineage of the North American genotype. J Fish Dis 29:611-619

Getchell RG, Culligan WJ, Kirschgessner M, Sutton CA, Casey RN, Bowser PR (2006) Quantitative polymerase chain reaction assay used to measure the prevalence of Clostridium botulinum type $\mathrm{E}$ in fish in the lower Great Lakes. J Aquat Anim Health 18:39-50

Gravell M, Malsberger RG (1965) A permanent cell line from the fathead minnow (Pimephales promelas). Ann NY Acad Sci 126:555-565

Editorial responsibility: Jo-Ann Leong, Kaneohe, Hawaii, USA
Hedrick RP, Batts WN, Yun S, Traxler GS, Kaufman J, Winton JR (2003) Host and geographic range extensions of the North American strain of viral hemorrhagic septicemia virus. Dis Aquat Org 55:211-220

Jude DJ, Reider RH, Smith GR (1992) Establishment of Gobiidae in the Great Lakes basin. Can J Fish Aquat Sci 49:416-421

Luna LG (ed) (1968) Manual of histological staining of the Armed Forces Institute of Pathology. McGraw-Hill, New York

Meyers TR, Sullivan J, Emmenegger E, Follett J, Short S, Batts WN, Winton JR (1992) Identification of viral hemorrhagic septicemia virus isolated from Pacific Cod Gadus macrocephalus in Prince William Sound, Alaska, USA. Dis Aquat Org 12:167-175

Meyers TR, Short S, Lipson K, Batts WN, Winton JR, Wilcock J, Brown E (1994) Association of viral hemorrhagic septicemia virus with epizootic hemorrhages of the skin in Pacific herring Clupea harengus pallasi from Prince William Sound and Kodiak Island, Alaska, USA. Dis Aquat Org 19:27-37

Noga EJ (1996) The clinical work-up and postmortem techniques. In: Noga EJ (ed) Fish disease: diagnosis and treatment. Mosby, St. Louis, MO, p 10-43

Office International des Epizooties (2003) Manual of diagnostic tests for aquatic animals, 4th edn. Office International des Epizooties, Paris

Schlotfeldt HJ, Ahne W, Vestergård-Jørgensen PE, Glende W (1991) Occurrence of viral haemorrhagic septicaemia virus in turbot (Scophthalmus maximus) - a natural outbreak. Bull Eur Assoc Fish Pathol 11(3):105-107

Winton JR, Batts WN, Deering RE, Brunson R, Hopper K, Nishizawa T, Stehr C (1991) Characteristics of the first North American isolates of viral hemorrhagic septicemia virus. In: Fryer JL (ed) Proc 2nd Intl Symp Viruses of Lower Vertebrates, Corvallis, Oregon, July 29-31, 1991. Oregon State University Printing Dept, Corvallis, OR, p 43-50

Wolf K (1988) Viral hemorrhagic septicemia. In: Fish viruses and fish viral diseases. Cornell University Press, Ithaca, NY, p 217-249

Submitted: August 29, 2006; Accepted: April 25, 2007 Proofs received from author(s): June 12, 2007 